\title{
The Potential Role of Smart Mobile Technology in Mitigating Ireland's Tourism Biosecurity Risk
}

\author{
Domhnall Melly, James Hanrahan \\ Institute of Technology, Sligo, Ireland
}

\begin{abstract}
The use of smart mobile technology could potentially ease Ireland's level of biosecurity risk from tourism. Smart mobile technology is capable of improving communication of biosecurity monitoring, mitigation, and eradication measures to tourists in Ireland. The scope of this research is to assess biosecurity communication from Ireland's major ports, state agencies, and governing bodies involved in outdoor recreational activities. The aim of this paper is to assess Ireland's biosecurity communication for any smart mobile technology in national agencies. A mixed method approach was utilised which consisted of content analysis as well as structured qualitative interviews. Analysis has revealed that no evidence of smart mobile technology for biosecurity communication is in place for tourists arriving in Ireland's ports or in national agencies. The importance of timely communication of biosecurity measures and alerts seems to not have been recognised. The use of this technology could mitigate the risk of tourists vectoring dangerous microbes and aiding biological invasions. This paper concludes that a low emphasis on adopting smart mobile technology could be unnecessarily contributing to Ireland's biosecurity risk. It offers an opportunity to be improved before a serious biosecurity breach occurs possibly resulting in a lost tourist season or expensive eradication programmes as has been witnessed in other destinations worldwide.
\end{abstract}

Keywords: tourism, biosecurity, Ireland, smart mobile technology, biosecurity alerts

\section{Introduction}

This paper focuses on the potential for smart mobile technology to mitigate Ireland's tourism biosecurity risk. Ireland's tourism industry contributes significantly to the Irish economy with $€ 8.8$ billion earnings in 2017 (Fáilte Ireland, 2018b). However, tourism is also known to generate negative impacts from a lack of biosecurity communication. Biosecurity breaches have the potential to significantly threaten human well-being and the environment (Vitousek 1994; Vitousek, D'antonio, Loope, \& Westbrooks, 1996; Clavero \& García-Berthou, 2005; Meyerson \& Mooney, 2007; Ricciardi, 2007; Crowl, Crist, Parmenter, Belovsky, \& Lugo, 2008; Hall, 2014). Infectious diseases can be transmitted from tourist vectoring to any part of the world (Baker, 2015). Both the 2003 Severe Acute Respiratory Syndrome (SARS) outbreak and the 2013 Ebola outbreak represent severe biosecurity breaches on human health. Furthermore, tourists partaking in outdoor recreational activities form a major pathway for IAS introductions (Pickering, Bear, \& Hill, 2007). The introduction of IAS has the potential to have significant impacts on biodiversity as well as serious economic and social consequences (EC

Domhnall Melly, BSc, Postgraduate Researcher, Department of Marketing, Tourism and Sport, Institute of Technology, Sligo, Ireland.

Dr. James Hanrahan, PhD, MSa, BA, Department of Marketing, Tourism and Sport, Institute of Technology, Sligo, Ireland. 
[European Commission], 2013; Jussila, Vrezec, Makkonen, Kortet, \& Kokko, 2015). It is estimated that the annual cost of invasive and non-native species to Ireland and Northern Ireland is $€ 261$ million (Kelly, Tosh, Dale, \& Jackson, 2013). Many governments have developed biosecurity strategies to mitigate biosecurity risk, namely "The Great Britain Invasive Non-native Species Strategy 2015" and "New Zealand: Biosecurity 2025". However, tourists may not be made aware of a strategy if adequate biosecurity communication is not in place. Therefore, tourist awareness is considered a crucial element for the implementation of biosecurity measures (Gunn, Heffernan, Hall, McLeod, \& Hovi, 2008; Palmer, Fozdar, \& Sully, 2009; Nöremark, Sternberg Lewerin, Ernholm, \& Frössling, 2016; Novoa, Dehnen-Schmutz, Fried, \& Vimercati, 2017). As a result, smart mobile technology could provide an effective communication method for biosecurity.

The rationale for this paper is centred around the dearth of academic research on biosecurity risk and smart mobile technology in Ireland. Current uses of smart mobile technology in tourism consist of personal blogs, review sites, and travel planning (Huang, Goo, Nam, \& Yoo, 2017). Adopting smart mobile technology into Ireland's biosecurity could potentially generate significant improvements in tourist communication. This may lead to a more efficient biosecurity surveillance and alert system and immediate implementation of biosecurity guidelines. The importance of biosecurity measures for tourism is widely acknowledged in scholarly literature (Pickering et al., 2007; Hall, 2014; Anderson, Rocliffe, Haddaway, \& Dunn, 2015; Findlater \& Bogoch, 2018). However, little academic literature relating to the use of smart mobile technology for tourist biosecurity communication exists.

The primary aim of this paper was to assess the extent smart mobile technology is being used for Ireland's biosecurity communication. This assessment of biosecurity communication has been conducted based on agencies use of smartphone apps, interactive airport signage, digital biosecurity officers, or any other forms of smart mobile technology. Forty one national agencies and state bodies for recreational activities and major ports in Ireland have been used in this research. All plans, policies, strategies, guidelines, and online media of these agencies have been thoroughly assessed. The findings from this paper are discussed in the context of international best practice to potentially reduce tourism biosecurity risk in Ireland.

\section{Literature Review}

\section{Biosecurity and Human Health}

The world has witnessed many recent biosecurity breaches in relation to human health. Notably, the Ebola outbreak of 2013 infected 28,646 people and resulted in 11,323 deaths (WHO [World Health Organisation], 2016). International travel is said to play a big role in contributing to the spread of these viruses worldwide (Findlater \& Bogoch, 2018). Furthermore, the growing popularity of airline transportation among tourists has heightened the risk for infectious diseases transmission (Mangili \& Gendreau, 2005). According to the UNWTO [United Nations World Tourism Organization] (2018), international tourist arrivals worldwide increased 7\% in 2017 compared to 2016, representing a total of 1,322 million. This substantial increase in international tourism highlights the importance of providing biosecurity communication to tourists in major ports.

The current volume, speed, and reach of international travel are unprecedented (Baker, 2015). Air travel has been implicated in the transportation of Ebola into areas of Europe from Africa (Parra, Salmerón, \& Velasco, 2014; CDC [Centres for Disease Control and Prevention], 2014; WHO, 2014a, 2014b, 2014c; Ross, Olveda, \& Yuesheng, 2014; WHO, 2018). Historically, containment and quarantine methods have been used as far back as the 14th century in order to control the trans-border spread of infectious diseases (MacPherson \& 
Gushlak, 2001). More recently, however, surveillance, responsive healthcare, vector control, and education programmes need to be in place to stop infectious disease spreading (Soto, 2009). These suggested measures are consistent with the idea that the screening of travellers at airports was ineffective and expensive (ACI [Airports Council International], 2009). Moreover, airport screening manifested negative psychological impacts among tourists. Without adequate biosecurity control measures communicated to tourists, airports reputation and confidence could be eroded overnight in times of pandemic crisis (Chung, 2015). Therefore, ineffective biosecurity communication of adequate mitigation measures at major ports has the potential to incur economic losses on the tourism industry.

Effective vector control measures in place could be seen as an effective measure for mitigating biosecurity risk from tourism. Hand washing procedures and disinfection measures effectively communicated to tourists may reduce the risk of disease (Bright, Boone, \& Gerba, 2010). However, the communication of biosecurity measures to tourists appears to be lacking (CDC, 2002; Mangili \& Gendreau, 2005). The use of smart technology may provide a convenient platform to communicate essential biosecurity mitigation measures to tourists.

\section{Human Health, Biosecurity, and Tourism in Ireland}

Ireland is becoming an increasingly popular destination for international tourists. Visitors from Mainland Europe increased over 7\% and 14\% from North America between 2015 and 2016 (Fáilte Ireland, 2016; 2018a). These increases highlight a potential serious biosecurity risk to Ireland. Increasing spatial movements of international tourists has resulted in a heightened risk of infectious diseases spreading due to reduced geographic barriers (Baker, 2015). This is due to tourism creating efficient transport systems for dangerous pathogens through tourist vectoring (Soto, 2009). The rapid international spread of SARS in 2003 from Hong Kong was significantly assisted by global travel (Moore, 2004). In addition, a wider diffusion of potential biosecurity threats is occurring due to tourists using smaller hub airports (Gaber, Goetsch, Diel, Doerr, \& Gottschalk, 2009). These smaller regional airports are fulfilling new functions and increasingly facilitate long haul flights (Warren, Bell, \& Budd, 2010). International tourists to Ireland are not only increasing in the larger "hub" airports. Regional airports, such as Ireland West Airport carried 750,000 passengers in 2017 (IWA [Ireland West Airport], 2018), the highest ever recorded in the airports history. Furthermore, Donegal Airport increased passenger numbers by $15.45 \%$ in the first quarter of 2017 compared to the same period in 2016 (DTTAS [Department of Transport, Tourism and Sport], 2017). In addition to airports, Irelands seaports remain a potential threat to biosecurity with 1.28 million sea passengers arriving to Ireland in 2016 (Marine Institute, 2017) and remain an increasingly significant contributor to Irish tourism. As a result, the Western region of Ireland witnessed 5.3\% growth in 2016 (Fáilte Ireland, 2016; 2018a). The possible increase in biosecurity risk may be due to tourists acting as an effective transport mechanism for dangerous microbes across borders (Brown \& Linham 1988; Slavin, Jennens, \& Tee, 1996; Harnett et al., 1998; Wilson, 2003). These may engage in behaviour that leads to transmission of pathogens through blood and body fluid exposure from other tourists (Breugelmans, Zucs, \& Porten, 2004). A wider dispersal of tourists to Ireland highlights the need for readily available biosecurity measures. The use of smart mobile technology could facilitate biosecurity measures to tourists while they are on the move. This could potentially result in increased biosecurity best practice measures by tourists and faster communication of biosecurity alert measures.

An additional issue of concern for biosecurity is that official communication from experts about a pandemic must compete with unofficial communication (Nerlich \& Koteyko, 2012). This is a result of social 
media platforms allowing the public to become the media themselves. Furthermore, the media often fuel imagery of destinations (Lepp \& Gibson, 2003; Taylor \& Toohey, 2007). This can communicate personal and physical security perceptions which lead to influencing tourists travel decisions (Kozak, Crotts, \& Law, 2007; Novelli, Burgess, Jones, \& Ritchie, 2018). This highlights the importance of agencies and state bodies providing timely biosecurity communication. Interestingly, the TRB (Transportation Research Board, 2013) identified communication as a key point to consider for managing infectious diseases incidents. Smart technology could communicate with passengers through multiple means. Airport websites, mobile applications, interactive biosecurity officer, and interactive airport signage could be adopted into Ireland's biosecurity. National agencies and state bodies in Ireland adopting these forms of technology could result in more accurate biosecurity information which tourists receive. Furthermore, smartphone apps could also be used to collect data on travel-associated infections and increase tourist compliance of biosecurity measures (Alqahtani et al., 2016).

\section{Biosecurity and the Environment}

Biosecurity has been defined as "the management of risks posed by organisms to the economy, environment, and human health through exclusion, mitigation, adaptation, control, and eradication" (Pyšek \& Richardson, 2010, p. 31). One of the major environmental concerns for biosecurity is the rate of new IAS. The establishment of non-native species outside of their natural range that threaten the functioning of ecosystems are known as biological invasions (Grosholz, 2002; Perrings, Dehnen-Schmutz, Touza, \& Williamson, 2005; Molnar, Gamboa, Revenga, \& Spalding, 2008; Poulin, 2017). Biological invasions can also lead to heavy economic burden being placed on the effected destination in eradication or control measures. In Europe alone, more than 10,000 non-native species have become invasive, costing €12bn per year (EEA [European Environmental Agency], 2012). Some of the main factors affecting the rate of biological invasions are climate change (Rahel \& Olden, 2008), increasing international trade (STDF [Standards and Trade Development Facility], 2013), globalisation (Perrings et al., 2005), and tourism (Anderson et al., 2015). Moreover, recreational activities are presumed to have been responsible for over a third of non-native species introductions into Europe (Gallardo \& Aldridge, 2013).

Existing research has focused on the role of outdoor recreational activities as a pathway for IAS in terrestrial environments, particularly in protected areas and national parks (Cowie \& Werner, 1993; Pickering et al., 2007; Allen, Brown, \& Stohlgren, 2008; Newsome, Smith, \& Moore, 2008; Barros \& Pickering, 2014). This is due to tourist's ability to create a pathway for the movement of IAS when participating in outdoor recreational activities (Anderson et al., 2015). Specifically, tourist activities, such as boating and angling are receiving increasing recognition as pathways for IAS (Rothlisberger, Chadderton, McNulty, \& Lodge, 2010; Kilian et al., 2012; Bacela-Spychalska, Grabowski, Rewicz, Konopacka, \& Wattier, 2013; Anderson, White, Stebbing, Stentiford, \& Dunn, 2014). An example is the arrival of the highly invasive algae Didymosphenia Geminate (Didymo) to New Zealand. This IAS caused highly destructive environmental impacts and resulted in an estimated economic loss of between $€ 34 \mathrm{~m}$ and $€ 169 \mathrm{~m}$ over the eight years (NZIER [New Zealand Institute of Economic Research], 2006). Recreational fishing equipment was the likely cause of this severe invasion of Didymo (Kilroy, 2004). The costly invasion of Didymo led to the "Check, Clean, Dry" biosecurity initiative that uses an active website, social media (MPI, 2016), and smartphone apps (MPI, 2017a; 2017b) for communication.

Biosecurity guidelines for anglers and boaters can mitigate the risk of hull fouling and other tourism pathways for IAS. However, biosecurity guidelines may be ineffective if they are not properly communicated 
to tourists. The use of smart technology could provide an efficient mechanism for promptly communicating and educating users of outdoor recreational activities. Smartphone apps could quickly inform tourists of important measures to mitigate the risk of potential biological invasions in a timely process and also facilitate a rapid IAS alert system for tourists and all water users.

\section{Environmental Biosecurity and Tourism in Ireland}

Ireland's natural environment and unspoilt surroundings are crucial to many of Fáilte Ireland and Tourism Ireland tourism campaigns. Tourist participation for recreational activities, such as angling, stand up paddling, and hiking/hillwalking in Ireland is increasing (Fáilte Ireland, 2015; 2016). However, this raises the prospect of high eradication costs for IAS and environmental damage. The loss of keystone species and pollinators, and altered ecosystems are cause for concern for tourists participating in outdoor recreational activities (Pyšek \& Richardson, 2010). Not only this, but IAS may also potentially depreciate from the economic value of the natural landscape (Stokes, O'Neill, \& McDonald, 2004). According to NBDC [National Biodiversity Data Centre, 2018), there are currently 128 IAS established in Ireland. Significantly, 51 of these are classed as high impact species. As a result, many control and eradication projects are being undertaken throughout Ireland. Lagarosiphon Major (Curly Leaved Waterweed) was identified in substantial quantities in Lough Corrib, Co. Galway (Caffrey \& Acevedo, 2008). In 2007, 300 tonnes of Curly Leaved Waterweed were removed from 4.7 ha of the lake at a cost of almost $€ 40,000$ in five days (CFB [Central Fisheries Board], 2007). Many authors have identified tourists as vectors of biosecurity threats (Cowie \& Werner, 1993; Pickering et al., 2007; Allen et al., 2008; Newsome et al., 2008; Barros \& Pickering, 2014). As tourists partaking in outdoor recreational activities can significantly contribute to the spread of IAS in Irish lakes, rivers, and woodlands, biosecurity communication is of high importance.

The control cost function of IAS is described as the cost of reducing the invader population by a given amount identical to removal costs (Olson \& Roy, 2008). However, the potential savings from implementing biosecurity pathway measures in Ireland has seldom been discussed. According to CFB (2007), once an IAS species has become established in a location, it can be hugely difficult and extremely costly to control or eradicate. Earlier preventative measures could be considered a more cost-effective approach to preventing biological invasions. Anderson (2015, p. 94) stated that "understanding and managing the pathways by which non-native species are introduced into new regions is considered the most effective way to prevent future biological invasions". Therefore, a lack of biosecurity communication to tourists may result in higher rates of IAS introductions on fishing gear, wetsuits, and hiking gear (Anderson et al., 2015). Surveillance measures, interception programmes, and early warning strategies are crucial for mitigating the risks of IAS (Hulme, 2006). However, knowledge of the pathways of initial introduction is crucial for the success of these measures (Hulme et al., 2008). Pathway and vector management has come into focus relatively recently (Carlton \& Ruiz, 2005) and can lead to various proactive biosecurity measures being implemented (Pyšek \& Richardson, 2010). Evidently, biosecurity guidelines are in place in Ireland for angling, boating, paddle sports, and scuba diving (IFI [Inland Fisheries Ireland], 2013). If properly implemented in Ireland, these measures could significantly strengthen pathway management in Ireland. However, communication of these measures to tourists may be lacking.

\section{Tourism Biosecurity Risk Mitigation}

Biosecurity risk mitigation can affect many different industries. Biosecurity threats can cross over into multiple industries for example tourism and agriculture when discussing agri-tourism. Evidently, Ireland and 
New Zealand share many similarities, such as biological isolation, and have both experienced the resulting advantages and disadvantages. Both have benefited from agriculture that has remained comparatively free of pests and diseases found elsewhere (Jaya, Morad, \& Bell, 2003). However, isolation for many years has left native species and ecosystems particularly vulnerable to the effects of exotic species (Brown, 1989; Clout \& Lowe, 2000). For this purpose, New Zealand has adopted a multi-industry approach in its biosecurity framework. This involves national and regional levels of government that cover surveillance, border control, and pre- and post- border control (Jaya et al., 2003). The MPI (Ministry for Primary Industries) comprises the MAF (Ministry of Agriculture and Forestry), MFish (Ministry of Fisheries), and NZFSA (New Zealand Food Safety Authority) to ensure a standardised biosecurity system. This approach was seen to synchronise various industries to a harmonized standard of biosecurity, while also advocating a collaborative approach from relevant stakeholders.

Tourism biosecurity mitigation can take many different approaches from entry screening at airports, to disinfection stations at popular tourist fishing locations. Improving the communication of biosecurity best practice guidelines may be an effective way of mitigating Ireland's tourism biosecurity risk. Reducing biological invasions through biosecurity management and mitigation through the tourism pathway will require effective prediction, surveillance, awareness-raising, and control. However, an element of communication is usually missing from many initial pathway mitigation frameworks (Hulme et al., 2008). The use of smart mobile technologies could potentially create efficiencies that are decisive for successful pathway management. Smartphones and other smart technologies can provide tourists with useful information due to easy accessibility and connection even during the traveling period (Huang et al., 2017). While Inland Fisheries Ireland provides vital biosecurity guidelines for the mitigation of risk for recreational tourist activities, the dissemination to tourists may be lacking. Furthermore, national agencies may be in an even greater advantageous position to mitigate Ireland's biosecurity risk. Smart mobile technology could provide vital biosecurity guidelines to tourists by developing smartphone apps and interactive airport signage. This could lead to increased tourist awareness and adoption of biosecurity best practice, such as cleaning footwear and recreational gear.

\section{The Smart Tourism Landscape}

Smart tourism is the typical example of integrated development by combining the tourism industry with technological innovations (Ma \& Liu, 2011). The concept of smart being applied to tourism is no surprise. This may be due to tourism being dependent on information and data in order to provide guidance on planning issues (Werthner \& Klein 1999; Law, Buhalis, \& Cobanoglu, 2014; Benckendorff, Sheldon, \& Fesenmaier, 2014; Koo, Gretzel, Hunter, \& Chung, 2015). Recent ICT (information communication technology) developments initiating smartness and smart places have been recognised to cause a paradigm shift within the tourism industry (Buhalis, 2015). This shift in the European tourism landscape mainly comprises of processes of developing smart end-user applications for enriched tourism experiences (Lamsfus, Martín, Alzua-Sorzabal, \& Torres-Manzanera, 2015; Boes, Buhalis, \& Inversini, 2015). However, in some countries, for instance, Australia, the emphasis is on smart governance (Gretzel, Sigala, Xiang, \& Koo, 2015).

The term "smart" according to Harrison et al. (2010) is defined as "exploiting operational, near-real-time real-world data, integrating and sharing data, and using complex analytics, modelling, optimization and visualization to make better operational decisions" (p. 1). In the context of tourism, smart is used to describe a "complex combination of fostering technology integration, multi-functionality and high levels of connectivity 
using smart phone, smart card, smart TV technology which will support new forms of collaboration and value creation that leads to innovation, entrepreneurship and competitiveness" (Gretzel et al., 2015, p. 179). The term smart is a relatively recent addition to tourism. However, although the European smart tourism landscape predominantly comprises tourism experiences, its potential for improvements for biosecurity communication is now clearer.

Tourism is becoming such an increasingly competitive marketplace where only the best-managed destinations will prosper (Buhalis, 2000). The formulation of strategies aimed at managing issues of visitation, sensitivity to local culture, and environmental problems are considered to be critical issues for managing tourism. The development of smart tourism in destinations provides convenient access to information for both tourism agencies, and the tourists themselves (Zhu, Zhang, \& Li, 2014). Smart tourism is ideally placed to meet the personalized demand of tourists, improving tourists' satisfaction, while realising the common sharing and intensive use of resources ( $\mathrm{Li}, \mathrm{Hu}$, Huang, \& Duan, 2017). Smart wireless technology has the ability to provide tourists with destination information on the go. Therefore, this leads to the acceptance that important destination guidelines could also be shared on similar platforms. New Zealand has already adopted smart technology for their biosecurity system through the development of smartphone applications called "NZ Arrivals" (MPI, 2017a) and "NZ Fishing" (MPI, 2017b). Similar smartphone apps in Ireland could potentially aid in the efficient communication of biosecurity measures to tourists. Smart technology applications could also enable key tourism stakeholders to manage destinations more effectively through collecting location, typology, and behaviour data.

\section{Methodology}

In order to undertake an assessment of smart mobile technology in Ireland's biosecurity communication, this study employed a mixed method approach. Initially, a theoretical framework was developed which informed the construction of a detailed content analysis tool that was utilised in tandem with structured qualitative interviews. Through an in-depth review of theory and international examples, the researchers identified 41 national and key agencies, state bodies, and major ports in Ireland. Through findings identified in international theory, the researchers understood that the selected sample would be in a favourable position to increase implementation of biosecurity measures for tourists in Ireland through smart mobile technology.

This assessment focused on strategic documents, plans, policies, guidelines, and media which were analysed to identify if smart mobile technology is utilised. Additionally, an assessment was also conducted on the presence of biosecurity alerts for tourism. A content analysis approach was used which "will allow for the objective, systematic and quantitative description of the manifest content of communication" (Berelson, 1952, p. 18). This will allow for an assessment of smart mobile technology for tourism biosecurity in Ireland. The specific type of content analysis approach chosen by a researcher varies with the theoretical and substantive interests of the researcher and the problem being studied (Weber, 1990). The data gathered were entered into a specifically designed tourism biosecurity matrix tool. This tool included specific criteria to be assessed through employing a content analysis method of research. This analysis focused on: (1) biosecurity communication through smart technology; (2) biosecurity alerts in place; and (3) biosecurity alert measures in place. Qualitative data within this study were attained by conducting structured qualitative interviews with senior personnel within the agencies. This qualitative data were analysed with qualitative software analysis Nvivo. The data were gathered between February and April of 2018 and were inputted into the tourism biosecurity matrix tool. 


\section{Sampling}

This research involved key and national agencies, and points of entry which were believed to be appropriate through purposive sampling. This method of sampling was used as it enabled the researchers to use their knowledge to determine who or what study units are most appropriate for inclusion (Jennings, 2010; Etikan, Musa, \& Alkassim, 2016). This assessment established key areas of biosecurity threat to Ireland from tourism. In addition, we identified the relevant stakeholders who may be in a position to improve biosecurity communication by using smart mobile technology. Forty one national agencies and state bodies were used for this assessment. The selected sample would be in a favourable position to increase biosecurity communication for tourists in Ireland.

\section{Result and Discussion}

The results indicate that $0 \%$ of respondents use smart mobile technology for biosecurity communication. The results also indicate that $10 \%$ of respondents provide biosecurity alerts, while the same $10 \%$ provide biosecurity measures for these alerts.

In order to successfully implement biosecurity measures, the issue of communication to tourists cannot be overlooked. Tourists themselves should be considered an integral part of the global surveillance network for emerging infections (Baker, 2015). Furthermore, smart mobile technology could inform biosecurity strategies that can be used to control infections in developing countries and prepare tourists to those areas. Despite its importance however, it was revealed that $0 \%$ of the 41 national agencies and state bodies assessed utilize any smart mobile technology (see Table 1).

Table 1

Matrix for Assessing Biosecurity Communication Through Smart Technology

\begin{tabular}{|c|c|c|c|c|}
\hline \multicolumn{2}{|c|}{ Criteria assessed } & $\begin{array}{l}\text { Biosecurity communication } \\
\text { through smart technology }\end{array}$ & $\begin{array}{l}\text { Biosecurity } \\
\text { alerts in place }\end{array}$ & $\begin{array}{l}\text { Biosecurity alert } \\
\text { measures in place }\end{array}$ \\
\hline \multirow{5}{*}{ 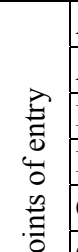 } & Angling Council of Ireland ${ }^{*}$ & & & \\
\hline & Angling Ireland & & $\mathrm{X}$ & $\mathrm{X}$ \\
\hline & Ballooning Ireland & & & \\
\hline & Bird Watch Ireland & & & \\
\hline & Canoeing Ireland ${ }^{*}$ & & $\mathrm{X}$ & $\mathrm{X}$ \\
\hline \multirow{5}{*}{ 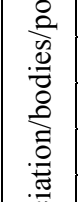 } & Cruising Association of Ireland & & & \\
\hline & Cycling Ireland $^{*}$ & & & \\
\hline & Donegal Airport & & & \\
\hline & Dublin Airport Authority & & & \\
\hline & Dublin Port & & & \\
\hline \multirow{8}{*}{ 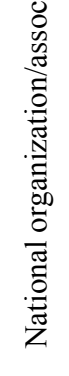 } & Fáilte Ireland & & & \\
\hline & Golfing Union of Ireland ${ }^{*}$ & & & \\
\hline & Heritage Boat Association & & & \\
\hline & Horse Sport Ireland $^{*}$ & & & \\
\hline & HSE (Health Service Excecutive) & & $\mathrm{X}$ & $\mathrm{X}$ \\
\hline & Inland Fisheries Ireland & & & \\
\hline & Inland Waterways Association of Ireland & & & \\
\hline & Irelands Association for Adventure Tourism & & & \\
\hline & Ireland West Airport & & & \\
\hline
\end{tabular}


(table 1 continued)

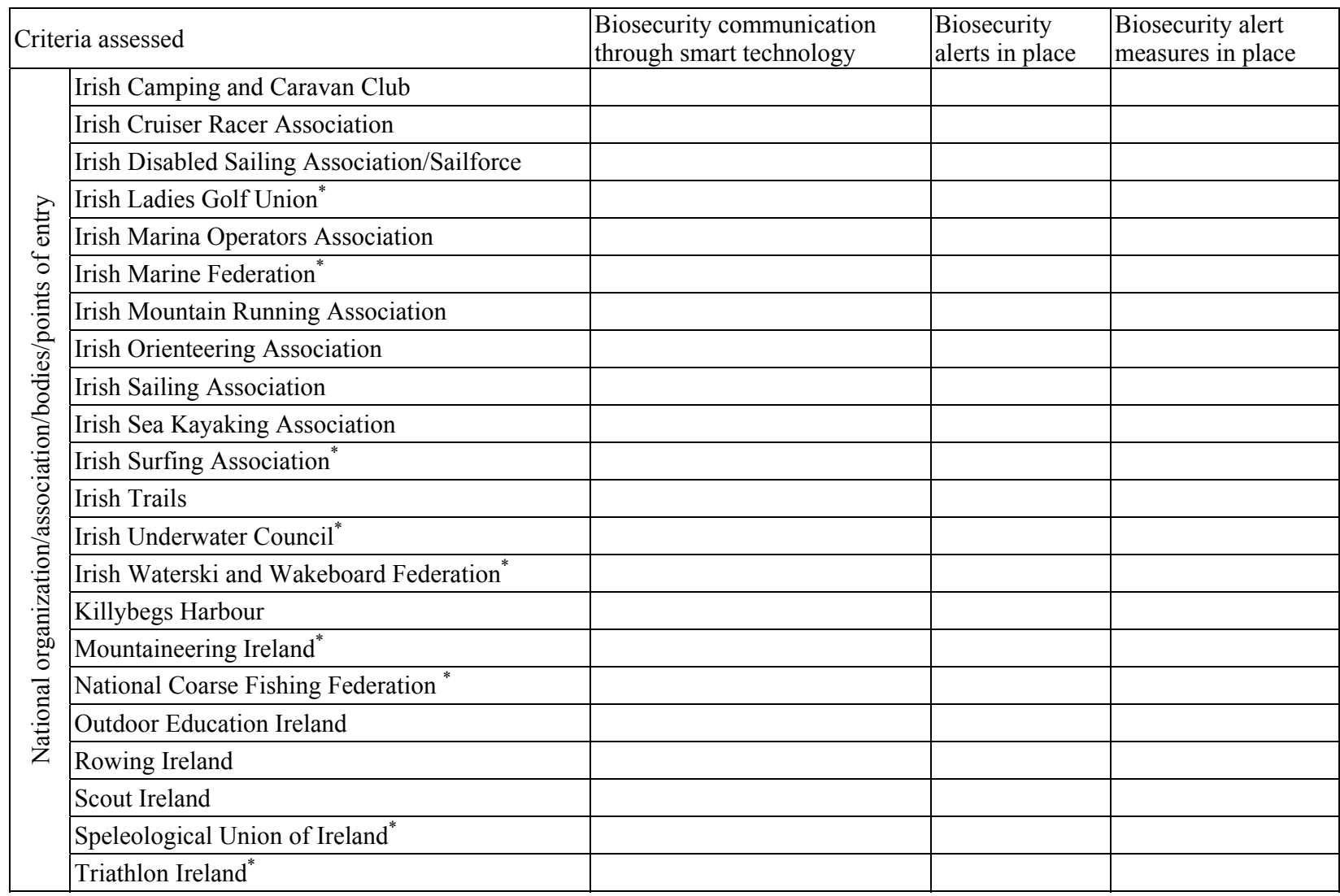

Notes. Key: $\mathrm{X}=$ Presence of a measure in place; ${ }^{*}=$ Governing body.

This is despite the evident importance of timely biosecurity communication when considering tourists potential to vector infectious diseases throughout the world. Wilson (2003) highlighted how tourists themselves can be not only victims, but also carriers and transmitters of microbial pathogens and increase the spread of infectious diseases worldwide. The HSE [Health Service Executive] is the state body in charge of public health services in Ireland. The HSE was found to have biosecurity alerts and alert measures in place for the event of a biosecurity breach. This alert process was located within the National Pandemic Influenza Plan for Ireland which was jointly developed with the DOHC [Department of Health and Children]. Significantly, this plan represents Irelands only biosecurity communication strategy. This plan outlines crucial methods of communication for an influenza pandemic. However, there is no evidence of smart mobile technology or wireless and mobile networks for this purpose. Instead, communication consists of leaflet drops, website, press briefings, and television and radio updates (HSE, 2007). Smart mobile technology is not present in any of Ireland's biosecurity communication. This is despite increased passenger traffic globally leading to a heightened level of risk for infectious diseases to be transported worldwide (Chung, 2015). The HSE's plan could do much more to educate and inform tourists more promptly by adopting more efficient communication channels.

Of significant importance to Ireland's environmental biosecurity risk, Inland Fisheries Ireland was found to have a biosecurity alert system in place. This was located on the state body's website. The purpose of this alert system is to initiate a preventative response to biological invasions as early as possible. This can have a 
significant impact on the success of the IAS species establishing. An increase in efficiency of a biosecurity alert system could increase participation of biosecurity best practice guidelines by tourists and avoid expensive biological invasions. It is important to note that once an IAS becomes established within a region, it is very difficult and can be very costly to control and remove. This has been witnessed with Curly Leaved Waterweed in Lough Corrib, Co. Galway (IFI, 2013). However, there was no evidence of smart mobile technology found to help communicate this biosecurity alert system. This is despite the potential for mobile technologies to interact with tourists partaking in outdoor recreational activities, while they are on the move. There was small evidence of an Inland Fisheries Ireland smartphone app on the agencies website. However, the IFI smartphone app was found to be inactive. This is despite Inland Fisheries Ireland having specific biosecurity guidelines for anglers, boaters, paddle sports, and scuba diving in place (IFI, 2013). The use of smart mobile technology could significantly increase tourist participation in these biosecurity guidelines and communicate biosecurity alert measures faster.

This was also the case with the two other agencies appearing to have biosecurity alert and alert measures in place. Both Angling Ireland and Canoeing Ireland utilise the alert system provided by Inland fisheries Ireland as part of a collaborative measure. This approach may create increased biosecurity awareness and improve biosecurity compliance by tourists. However, this could be enhanced by communicating alerts through smartphone apps. None of the 41 national agencies or state bodies use smart mobile technology. This is despite an increase in tourist popularity of hiking/cross country walking, and other high risk activities in Ireland (Fáilte Ireland, 2017). Although $10 \%$ of the samples provide biosecurity alert measures, there is no active smart mobile technology in place that could communicate them. This is worrying given the expensive eradication costs of IAS in Ireland (CFB, 2007; IFI, 2013, 2015). Awareness raising initiatives in New Zealand have proven successful in improving the biosecurity practices of recreational water users and airline passengers (Wittenberg \& Cock, 2001; Anderson et al., 2014; KDPP [Kauri Dieback Programme Partners], 2014). Furthermore, increasing awareness has the potential to increase biosecurity compliance by $71 \%$ of water users (Anderson, 2015). Significant biosecurity compliance could also be achieved in Ireland by agencies and state bodies using smart mobile technology. However, results show a potential disparity in Ireland's biosecurity. Moreover, the importance of pathway management has been highlighted by many authors (Hulme, 2006; Hulme et al., 2008; Hulme, 2009; Pyšek \& Richardson, 2010; Azmi, Primo, Hewitt, \& Campbell, 2015). However, communication remains missing from many initial pathway frameworks (Hulme et al., 2008). As a result, although pathway management measures are in place, they may not be fully implemented and practiced (Anderson et al., 2014).

\section{Conclusions}

It has been established that $0 \%$ of national agencies use smart mobile technology for the communication of biosecurity. This is worrying when the rapid growth of tourists visiting Ireland is considered. Therefore, this assessment provides clear direction for future development of communication strategies from national agencies, state bodies and major ports to include smart mobile technology. Effective international examples include smartphone apps and interactive biosecurity officers. Biosecurity information on the use of live bait while angling (Padilla \& Williams, 2004), and the cleaning and drying of angling and canoeing equipment before being transported into another water body (Anderson et al., 2014) are of high importance. This information could be communicated to tourists in Ireland through smartphone apps similar to New Zealand's "NZ Arrivals" 
(MPI, 2017a) and "NZ Fishing" (MPI, 2017b). Recreational activities are a known contributor to biosecurity risk. However, recreational activity agencies showed no evidence of smart mobile technology to communicate existing biosecurity guidelines or biosecurity alerts to tourists.

In relation to human health, crucial biosecurity alerts are in place that coincides with the WHO pandemic alert phase system. However, the National Pandemic Influenza Plan does not use smart mobile technology. The use of smartphone apps or real-time alerts on mobile devices could inform tourists who are on the move. Furthermore, there was also no evidence of smart technology for any of the major ports analysed. According to Chen (2009), tourists can enjoy computer capabilities and information resources without any obstacles through portable or wearable devices. New Zealand has already adopted smart mobile technology in their approach to biosecurity by developing smartphone apps and a digital biosecurity officer at Auckland airport. Such smart technology could potentially be used to disseminate biosecurity information through text, pictures, videos, and other products made by tourism enterprises (Li et al., 2017).

\section{Discussion and Suggestion}

This research has highlighted the importance of tourist biosecurity communication through smart mobile technology. The assessment focuses on effective smart mobile technology from national agencies and state bodies of outdoor recreational activities and at major ports to tourists. Improved biosecurity communication can increase agency support of a biosecurity strategy by increasing awareness among tourists. Furthermore, it can also raise awareness of initiatives, such as "Be Plant Wise" and "Check, Clean, Dry". The rapid information sharing associated with smart forms of communication technology can create more efficient information exchange and rapid response required for major biosecurity incidents. The importance of biosecurity communication was also witnessed with the Mexico Swine Flu pandemic where an entire tourist season was lost from a lack of expert communication. The faster dissemination of biosecurity information from experts could have alleviated tourist's fears. While the WHO pandemic alert phases are designed to keep the public and indeed tourists updated on the biosecurity status, improved methods of communication may be required. Apparent from the $0 \%$ of national agencies and state bodies in Ireland using smart technology for their biosecurity communication, there is a noticeable absence of acknowledgement of its importance. This is despite smart tourism in destinations providing convenient access to information for both tourism agencies and tourists (Zhu et al., 2014). The development of a smartphone app for improving biosecurity communication could potentially reduce biological invasions and infectious diseases being vectored into Ireland. Furthermore, smart mobile technology could be a much more economically sustainable approach in contrast to expensive control, eradication, and healthcare costs associated with a biosecurity breach.

The importance of technology as a strategic tool for tourism has been long recognized (Poon, 1993). Furthermore, Friedman (2016) noted how 2007 was a major turning point in that the release of the iPhone, together with advances in hardware, software, storage, sensors, and networking, spurring on an age of digital information. This widespread diffusion of technologies and devices occurred not only in homes and offices but also in many other physical environments (Xiang, 2018). This allows the free movement of information to tourists on the move. This is comparable to New Zealand's biosecurity adopting smart mobile technology. In 2017, "NZ Arrivals" (MPI, 2017a) and "NZ Fishing" (MPI, 2017b) smartphone apps were put in place to improve awareness and communication of biosecurity risks and measures to tourists. 
Despite smart mobile technology's advantages, none of the agencies or state bodies assessed had this technology in place. There was however evidence of an inactive smartphone app located on the website of a state body. This potentially signifies an acknowledgement of its usefulness for providing real time information to tourists and possibly integrating an alert system where tourists could report sightings of IAS. However, agencies need to go further and fully adopt this technology.

Digital biosecurity officers are already utilized in New Zealand and they provide tourists with constant biosecurity updates. Furthermore, smartphone apps could provide constant information to tourists while they are on the move. This trait is void from conventional communication processes, such as leaflet drops. This technology can also initiate biosecurity alerts faster and a successful biosecurity risk mitigation process. Although $10 \%$ of the national agencies assessed have biosecurity alerts in place, the communication of these alerts may be lacking. Smart technology could disseminate warning of outbreaks, the WHO pandemic phase situation, and precautionary measures in real time to tourists before, during, and after they travel. Moreover, timely top down communication from medical experts in Ireland is essential as it may have to compete with unofficial sources. Therefore, policy-makers should encourage the use of smart mobile technology in the development of communication strategies at a national level.

The $0 \%$ of national agencies using smart mobile technology gives a clear indication of the potential for improvement in biosecurity communication in Ireland. However, this study is not without limitations due to budget and time factors. The importance of biosecurity communication from national agencies, state bodies, and major ports is recognised. However, it would have been useful to include tourists themselves. Assessing tourists may form a different understanding of the level of biosecurity information which they receive and through what communication methods. Future studies may identify a clearer understanding of the most effective ways to improve biosecurity communication to tourists.

\section{References}

Airports Council International (ACI). (2009). Airport preparedness guidelines for outbreaks of communicable disease, International Civil Aviation Organization. Retrieved from https:/aci.aero/Media/8dd8ad43-9f9f-4fcc-bb37-6668383ef399/ LEfW0A/About\%20ACI/Priorities/Health/Airport_preparedness_guidelines_for_outbreaks_of_communicable.pdf

Allen, J. A., Brown, C. S., \& Stohlgren, T. J. (2008). Non-native plant invasions of United States National Parks. Biological Invasions, 11, 2195-2207.

Alqahtani, A. S., BinDhim, N. F., Tashani, M., Willaby, H. W., Wiley, K. E., Heywood, A. E., ... Rashid, H. (2016). Pilot use of a novel smartphone application to track traveller health behaviour and collect infectious disease data during a mass gathering: Hajj pilgrimage 2014. Journal of Epidemiology and Global Health, 6(3), 147-155.

Anderson, L. G. (2015). Managing aquatic non-native species: The role of biosecurity (Ph.D. thesis, University of Leeds).

Anderson, L. G. Rocliffe, S., Haddaway, N. R., \& Dunn, A. M. (2015). The role of tourism and recreation in the spread of non-native species: A systematic review and meta-analysis. PLOS ONE, 10 (10), 1-15.

Anderson, L. G., White, P. C. L., Stebbing, P. D., Stentiford, G. D., \& Dunn, A. M. (2014). Biosecurity and vector behaviour: Evaluating the potential threat posed by Anglers and Canoeists as pathways for the spread of invasive non-native species and pathogens. PLoS ONE, 9(4), 1-10.

Azmi, F., Primo, C., Hewitt, C. L., \& Campbell, M. L. (2015). Assessing marine biosecurity risks when data are limited: Bioregion pathway and species-based exposure analyses. ICES Journal of Marine Science, 72, 1078-1091.

Bacela-Spychalska, K., Grabowski, M., Rewicz, T., Konopacka, A., \& Wattier, R. (2013). The "killer shrimp" Dikerogammarus Villosus (Crustacea, Amphipoda) invading alpine lakes: Overland transport by recreational boats and scuba-diving gear as potential entry vectors? Freshwater Biology, 62, 1036-1051.

Baker, D. (2015). Tourism and the health effects of infectious diseases: Are there potential risks? International Journal of Safety \& Security in Hospitality \& Tourism, 12(1), 41-59. 
Barros, A., \& Pickering, C. M. (2014). Non-native plant invasion in relation to tourism use of Aconcagua Park, Argentina, the highest protected area in the Southern Hemisphere. Mountain Research and Development, 34, 13-26.

Benckendorff, P., Sheldon, P., \& Fesenmaier, D. R. (2014). Tourism information technology. Oxford: CAB International.

Berelson, B. (1952). Content analysis in communication research. Glencoe, Illinois: The Free Press.

Boes, K., Buhalis, D., \& Inversini, A. (2015). Conceptualising smart tourism destination dimensions. In I. Tussyadiah and A. Inversini (Eds.), Information and communication technologies in tourism 2015 (pp. 391-403). Heidelberg: Springer.

Breugelmans, J. G., Zucs, P., \& Porten, K. (2004). SARS transmission and commercial aircraft. Journal of the American Medical Association, 10(8), 1502-1503.

Bright, K., Boone, S. A., \& Gerba, C. P. (2010). Occurrence of bacteria and viruses on elementary classroom surfaces and the potential role of classroom hygiene in the spread of infectious diseases. Journal of School Nursing, 26(1), 33-41.

Brown, E. M., \& Linham, V. (1988). The importation of multiple resistant bacterial pathogens into a British hospital. Journal of Hospital Infections, 12, 138-139.

Brown, J. H. (1989). Patterns, modes and extents of invasions by vertebrates. In J. A. Drake et al. (Eds.), Biological invasions a global perspective (pp. 85-111). Chichester, New York: Wiley.

Buhalis, D. (2000). Marketing the competitive destination of the future. Tourism Management, 21(1), 97-116.

Buhalis, D. (2015). Working definitions of smartness and smart tourism destination. Unwto 3rd Global Summit on City Tourism: New Paradigms in City Tourism Development. Retrieved 19/02/2018 from http://buhalis.blogspot.co.uk/2014/12/workingdefinitions-of-smartness-and.html

Caffrey, J. M., \& Acevedo, S. (2008). Lagarosiphon major in Lough Corrib-Management options. In C. Moriarty, R. Rosell, and P. Gargan (Eds.), Fish stocks and their environment (pp. 85-97). Westport, Co Mayo: Institute of Fisheries Management.

Carlton, J. T., \& Ruiz, G. M. (2005). Vector science and integrated vector management in bioinvasion ecology: Conceptual frameworks. In H. A. Mooney, R. N. Mack, J. A. McNeely, L. E. Neville, P. J. Schei, and J. K. Waage (Eds.), Invasive alien species (pp. 36-58). Washington, DC: Island Press.

Centers for Disease Control and Prevention (CDC). (2002). Guidelines for hand hygiene in health care settings. Morbidity and Mortality Weekly Report (MMWR), 51, 16.

CDC. (2014). CDC and Texas health department confirm first Ebola case diagnosed in the U.S. Retrieved 06/02/2018 from http://www.cdc.gov/media/releases/2014/s930- ebola-confirmed-case.html

Central Fisheries Board (CFB). (2007). Status and management of lagarosiphon major in Lough Corrib 2007. Retrieved 14/02/2018 from http://www.fisheriesireland.ie/documents/151-status-and-management-of-lagarosiphon-major-in-lough-corrib $-2007-1 /$ file.html

Chen, R. (2009). Ubiquitous is the trends of ICT and network. Digital Communication World, 8, 12-14.

Chung, L. H. (2015). Impact of pandemic control over airport economics: Reconciling public health with airport business through a streamlined approach in pandemic control. Journal of Air Transport Management, 44, 42-53.

Clavero, M., \& García-Berthou, E. (2005). Invasive species are a leading cause of animal extinctions. Trends in Ecology and Evolution, 20(3), 110.

Clout, M. N., \& Lowe, S. J. (2000). Invasive species and environmental changes in New Zealand. In H. A. Mooney and R. J. Hobbs (Eds.), Invasive species in a changing world (pp. 369-384). Washington, DC: Island Press.

Cowie, I. D., \& Werner, P. A. (1993). Alien plant species invasive in Kakadu National Park, Tropical Northern Australia. Biological Conservation, 63, 127-135.

Crowl, T. A., Crist, T. O., Parmenter, R. R., Belovsky, G., \& Lugo, A. E. (2008). The spread of invasive species and infectious disease as drivers of ecosystem change. Frontiers in Ecology and the Environment, 6(5), 238-246.

Department of Transport, Tourism and Sport (DTTAS). (2017). DTTAS quarterly aviation statistics snapshot: Regional Airports Quarter 12017 Report. Retrieved 12/04/2018 from http:/www.dttas.ie/sites/default/files/content/aviation/English/general/ DTTAS\%20Quarterly\%20Aviation\%20Statistics\%20Snapshot\%20/regional-aviation-statistics-quarter-1-2017.pdf

Etikan, I. Musa, S.A. Alkassim, R.S. (2016). Comparison of convenience sampling and purposive sampling. American Journal of Theoretical and Applied Statistics, 5(1), 1-4.

European Commission (EC). (2013). Proposal for a regulation of the European parliament and of the council on the prevention and management of the introduction and spread of invasive alien species. Retrieved 14/11/2018 from $\mathrm{http} / / / w w w . e u r o p a r l . e u r o p a . e u / m e e t d o c s / 2009 \_2014 /$ documents/com/com_com(2013)0620_/com_com(2013)0620_en.pdf

European Environmental Agency (EEA). (2012). The impacts of invasive alien species in Europe. European Environmental Agency Technical Report, 16, 1-118. 
Fáilte Ireland. (2015). Activity product usage among overseas tourists in 2014. Retrieved 11/04/2018 from http://www.failteireland.ie/FailteIreland/media/WebsiteStructure/Documents/3_Research_Insights/1_Sectoral_SurveysRepor ts/Activity-product-usage-among-overseas-tourists-in-2014.pdf?ext=.pdf

Fáilte Ireland. (2016). Tourism facts 2015. Retrieved 11/04/2018 from http://www.failteireland.ie/FailteIreland/media/Website Structure/Documents/3_Research_Insights/3_General_SurveysReports/Tourism-Facts-2015-Preliminary.pdf?ext=.pdf

Fáilte Ireland. (2018a). Tourism facts 2016: Revised March 2018. Retrieved 09/04/2018 from http://www.failteireland.ie/ FailteIreland/media/WebsiteStructure/Documents/3_Research_Insights/2_Regional_SurveysReports/Tourism-Facts-2016-Re vised-March-2018.pdf?ext=.pdf

Fáilte Ireland. (2018b). Tourism facts 2017. Retrieved 12/10/2018 from http://www.failteireland.ie/FailteIreland/media/ WebsiteStructure/Documents/3_Research_Insights/5_International_Tourism_Trends/Tourism-Facts-2017_1.pdf?ext=.pdf

Fáilte Ireland. (2017). Tourism facts 2016. Retrieved 14/02/2018 from http://www.failteireland.ie/FailteIreland/media/Website Structure/Documents/3_Research_Insights/3_General_SurveysReports/Tourism-Facts-2016.pdf?ext=.pdf

Findlater, A., \& Bogoch, I. I. (2018). Human mobility and the global spread of infectious diseases: A focus on air travel. Trends in Parasitology, 34(9), 772-783.

Friedman, T. L. (2016). Thank you for being late: An optimist's guide to thriving in the age of accelerations. New York: Farrar, Straus and Giroux.

Gaber, W., Goetsch, U., Diel, R., Doerr, H. W., \& Gottschalk, R. (2009). Screening for infectious diseases at international airports: The Frankfurt model. Aviation, Space, and Environmental Medicine, 80, 595-600.

Gallardo, B., \& Aldridge, D. C. (2013). The "dirty dozen": Socio-economic factors amplify the invasion potential of 12 High-Risk aquatic invasive species in Great Britain and Ireland. Journal of Applied Ecology, 50, 757-766.

Gretzel, U., Sigala, M., Xiang, Z., \& Koo, C. (2015). Smart tourism: Foundations and developments. Electronic Markets, 25, 179-188.

Grosholz, E. D. (2002). Ecological and evolutionary consequences of coastal invasions. Trends in Ecology \& Evolution, 17, 22-27.

Gunn, G. J., Heffernan, C., Hall, M., McLeod, A., \& Hovi, M. (2008). Measuring and comparing constraints to improved biosecurity amongst GB farmers, veterinarians and the auxiliary industries. Preventive Veterinary Medicine, 84, 310-323.

Hall, C. M. (2014). Tourism and biological exchange and invasions: A missing dimension in sustainable tourism? Tourism Recreation Research, 40(1), 81-94.

Harnett, N., McLeod, S., AuYong, Y., Wan, J., Alexander, S., Khakhia, R., \& Krishnan, C. (1998). Molecular characterization of multiresistant strain of Salmonella Typhi from South Asia Isolated in Ontario, Canada. Canadian Journal of Microbiology, 44, 356-363.

Harrison, C., Eckman, B., Hamilton, R., Hartswick, P., Kalagnanam, J., Paraszczak, J., \& Williams, P. (2010). Foundations for smarter cities. IBM Journal of Research and Development, 54(4), 1-16.

Health Service Executive (HSE). (2007). National pandemic influenza plan and pandemic influenza preparedness for Ireland-Advice of the Pandemic Influenza Expert Group. Retrieved 14/11/2018 from https://health.gov.ie/wp-content/ uploads/2014/03/nationalfluplan.pdf

Huang, C. D., Goo, J., Nam, K., \& Yoo, C. W. (2017). Smart tourism technologies in travel planning: The role of exploration and exploitation. Information \& Management, 54(6), 757-770.

Hulme, P. E. (2006). Beyond control: Wider implications for the management of biological invasions. Journal of Applied Ecology, $43,835-847$.

Hulme, P. E. (2009). Trade, transport and trouble: Managing invasive species pathways in an era of globalization. Journal of Applied Ecology, 46(1), 10-18.

Hulme, P. E., Bacher, S., Kenis, M., Klotz, S., Kühn, I., Minchin, D., ... Vilà, M. (2008). Grasping at the routes of biological invasions: A framework to better integrate pathways into policy. Journal of Applied Ecology, 45, 403-414.

Inland Fisheries Ireland (IFI). (2013). Invasive species and biosecurity publications. Retrieved 28/03/2018 from https://www. fisheriesireland.ie/Research/invasive-species.html

IFI. (2015). Post-trial dredge report: Hot water section lanes borough. Retrieved 28/03/2018 from http://www.fisheriesireland.ie /invasive-species-1/533-post-trial-dredge-report-hot-water-section-lanesborough/file

Ireland West Airport (IWA). (2018). Ireland west airport records highest ever passenger numbers as 750,000 passengers use the airport in 2017. Retrieved 12/04/2018 from http://www.irelandwestairport.com/news/ireland-west-airport-records-highestever-passenger-numbers- 
Jaya, M., Morad, M., \& Bell, A. (2003). Biosecurity: A policy dilemma for New Zealand. Land Use Policy, 20, 121-129.

Jennings, G. (2010). Tourism research (1st ed.). Australia: Wiley and Sons.

Jussila, J., Vrezec, A., Makkonen, J., Kortet, R., \& Kokko, H. (2015). Invasive crayfish and their invasive diseases in Europe with the focus on the virulence evolution of the crayfish plague. Creative Commons Attribution, 8, 184-204.

Kauri Dieback Programme Partners (KDPP). (2014). Keep kauri standing: Stop kauri dieback disease spreading. Retrieved 12/04/2018 from http://www.kauridieback.co.nz/

Kelly, J., Tosh, D., Dale, K., \& Jackson, A. (2013). The economic cost of invasive and non-native species in Ireland and Northern Ireland: A report prepared for the Northern Ireland Environment Agency and National Parks and Wildife Service as part of invasive species Ireland. Retrieved 01/11/2018 from https://invasivespeciesireland.com/wp-content/uploads/2010/07/ Economic_Impact_Assessment_FINAL_280313.pdf

Kilian, J. V., Klauda, R. J., Widman, S., Kashiwagi, M., Bourquin, R., Weglein, S., \& Schuster, J. (2012). An assessment of a bait industry and angler behavior as a vector of invasive species. Biological Invasions, 14(7), 1469-1481.

Kilroy, C. (2004). A new alien diatom, Didymosphenia Geminata (Lyngbye) schmidt: Its biology, distribution, effects and potential risks for New Zealand fresh waters. Retrieved 02/02/2018 from http://www.biosecurity.govt.nz/files/pests/didymo/ didymo-preliminary-org-ia-nov-04.pdf

Koo, C., Gretzel, U., Hunter, W. C., \& Chung, N. (2015). The role of IT in tourism. Asia Pacific Journal of Information Systems, 25(1), 99-104.

Kozak, M., Crotts, J., \& Law, R. (2007). The impact of the perception of risk on international travellers. International Journal of Tourism Research, 9, 233-242.

Lamsfus, C., Martín, D., Alzua-Sorzabal, A., \& Torres-Manzanera, E. (2015). Smart tourism destinations: An extended conception of smart cities focusing on human mobility. In I. Tussyadiah and A. Inversini (Eds.), Information and communication technologies in tourism (pp. 363-375). Heidelberg, Germany: Springer.

Law, R., Buhalis, D., \& Cobanoglu, C. (2014). Progress on information and communication technologies in hospitality and tourism. International Journal of Contemporary Hospitality Management, 26(5), 727-750.

Lepp, A., \& Gibson, H. (2003). Tourist roles, perceived risk and international tourism. Annals of Tourism Research, 30(3), 606-624.

Li, Y., Hu, C., Huang, C., \& Duan, L. (2017). The concept of smart tourism in the context of tourism information services. Tourism Management, 58, 293-300.

Ma, Y., \& Liu, J. (2011). The enormous prospects of the smart tourism applications. China Tourism News, 2011-08-24, p. 13.

MacPherson, D. W., \& Gushlak, B. D. (2001). Human mobility and population health: New approaches in a globalising world. Perspectives in Biology and Medicine, 44, 390-401.

Mangili, A., \& Gendreau, M. A. (2005). Transmission of infectious diseases during commercial air travel. Lancet 2005, 365, 989-996.

Marine Institute. (2017). Ireland's port traffic remains strong in 2016 despite challenging trading environment. Retrieved 14/04/2018 from https://www.marine.ie/Home/site-area/news-events/news/ireland\%E2\%80\%99s-port-traffic-remainsstrong-2016-despite-challenging-trading

Meyerson, L. A., \& Mooney, H. A. (2007). Invasive alien species in an era of globalization. Frontiers in Ecology and the Environment, 5(4), 199-208.

Ministry for Primary Industries (MPI). (2016). MPI recreational fishing initiative. Retrieved 13/11/2018 from https://www. fisheries.govt.nz/dmsdocument/11842/loggedIn

Ministry for Primary Industries (MPI). (2017a). Travel and recreation: Items to declare. NZ Arrivals Smartphone Application. Retrieved 10/12/2017 from http://mpi.govt.nz/travel-and-recreation/arriving-in-new-zealand/items-to-declare/

MPI. (2017b). Central recreational fishing rules. Recreational Area Brochure. Retrieved 10/12/2017 from file://C:/Users/s00132849/Downloads/2017-December-Central-Recreational-Area-brochure-A4-web-version\%20(1).pdf

Molnar, J. L., Gamboa, R. L., Revenga, C., \& Spalding, M. D. (2008). Assessing the global threat of invasive species to marine biodiversity. Frontiers in Ecology and the Environment, 6, 485-492.

Moore, D. W. (2004). SARS: Preventative plans key to managing health risk in a construction environment in China. Professional Safety, March, 18-24.

National Biodiversity Data Centre (NBDC). (2018). Species designation browser, invasive species. Retrieved 07/02/2018 from http://maps.biodiversityireland.ie/\#/Designation /1/DesignationGroup 
Nerlich, B., \& Koteyko, N. (2012). Crying wolf? Biosecurity and metacommunication in the context of the 2009 swine flu pandemic. Health \&Place, 18, 710-717.

New Zealand Institute of Economic Research (NZIER). (2006). Didymosphenia geminata economic impact assessment. Final Report to Biosecurity New Zealand. Retrieved 23/04/2018 from http://www.didymo.net/files/didymo-econ-ia-mar-06.pdf

Newsome, D., Smith, A., \& Moore, S. A. (2008). Horse riding in protected areas: A critical review and implications for research and management. Current Issues in Tourism. 11, 144-166.

Nöremark, M., Sternberg Lewerin, S., Ernholm, L., \& Frössling, J. (2016). Swedish farmers' opinions about biosecurity and their intention to make professionals use clean protective clothing when entering the stable. Frontiers in Veterinary Science, 3(46), 1-13.

Novelli, M., Burgess, L. G., Jones, A., \& Ritchie, B. W. (2018). "No Ebola ... still doomed”-The Ebola-induced tourism crisis. Annals of Tourism Research, 70, 76-87.

Novoa, A., Dehnen-Schmutz, K., Fried, J., \& Vimercati, G. (2017). Does public awareness increase support for invasive species management? Promising evidence across taxa and landscape types. Biological Invasions, 19, 3691-3705.

Olson, L. J., \& Roy, S. (2008). Controlling a biological invasion: A non-classical dynamic economic model. Economic Theory, 36(3), 453-469.

Padilla, D. K., \& Williams, S. L. (2004). Beyond ballast water: Aquarium and ornamental trades as sources of invasive species in aquatic ecosystems. Frontiers in Ecology and the Environment, 2, 131-138.

Palmer, S., Fozdar, F., \& Sully, M. (2009). The effect of trust on West Australian farmers' responses to infectious livestock diseases. Sociologia Ruralis, 49, 360-374.

Parra, J. M., Salmerón, O. J., \& Velasco, M. (2014). The first case of Ebola virus disease acquired outside Africa. The New England Journal of Medicine, 371(25), 2439-2440.

Perrings, C., Dehnen-Schmutz, K., Touza, J., \& Williamson, M. (2005). How to manage biological invasions under globalization. Trends in Ecology \& Evolution, 20, 212-215.

Pickering, C. M., Bear, R., \& Hill, W. (2007). Indirect impacts of nature based tourism and recreation: The association between infrastructure and the diversity of exotic plants in Kosciuszko National Park, Australia. Journal of Ecotourism, 6, 146-157.

Poon, A. (1993). Tourism, technology and competitive strategies. New York: CAB International.

Poulin, R. (2017). Invasion ecology meets parasitology: advances and challenges. International Journal for Parasitology: Parasites and Wildlife, 6(3), 361-363.

Pyšek, P., \& Richardson, D. M. (2010). Invasive species, environmental change, management, and health. The Annual Review of Environment and Recourses, 35, 25-55.

Rahel, F. J., \& Olden, J. D. (2008). Assessing the effects of climate change on aquatic invasive species. Conservation Biology, 22, 521-533.

Ricciardi, A. (2007). Are modern biological invasions an unprecedented form of global change? Conservation Biology, 21, 329-336.

Ross, A. G. P., Olveda, R. M., \& Yuesheng, L. (2014). Are we ready for a global pandemic of Ebola virus? International Journal of Infectious Diseases, 28, 217-218.

Rothlisberger, J. D., Chadderton, W. L., McNulty, J., \& Lodge, D. M. (2010). Aquatic invasive species transport via trailered boats: What is being moved, who is moving it, and what can be done. Fisheries, 35, 121-132.

Slavin, M., Jennens, I., \& Tee, K. W. K. (1996). Infection with ciprofloxacin-resistant campylobacter Jejuni in travellers returning from Asia. European Journal of Clinical Microbiology and Infectious Diseases, 15, 48-50.

Soto, S. M. (2009). Human migration and infectious diseases. Clinical Microbiology and Infection, 15(1), 26-28.

Standards and Trade Development Facility (STDF). (2013). International trade and invasive alien species. Retrieved 23/04/2018 from http://oie.int/doc/ged/D13294.PDF

Stokes, K., O’Neill, K., \& McDonald, R. A. (2004). Invasive species in Ireland (Unpublished Report to Environment \& Heritage Service and National Parks \& Wildlife Service, Quercus, Queens University Belfast).

Taylor, T., \& Toohey, K. (2007). Perceptions of terrorism threats at the 2004 Olympic Games: Implications for sporting events. Journal of Sports Tourism, 12(2), 99-114.

Transportation Research Board (TRB). (2013). Infectious disease mitigation in airports and on aircraft. Airport Cooperative Research Program (ACRP) Report 91. Retrieved 20/04/2018 from https://crp.trb.org/acrp0331/wp-content/uploads/sites/7/ 2016/11/ACRPResources.pdf 
United Nations World Tourism Organization (UNWTO). (2018). 2017 international tourism results: The highest in seven years. Retrieved 6/02/2018 from http://media.unwto.org/press-release/2018-01-15/2017-international-tourism-results-highest-seven-years Vitousek, P. M. (1994). Beyond global warming: Ecology and global change. Ecology, 75, 1861-1876.

Vitousek, P. M., D'antonio, C. M., Loope, L., \& Westbrooks, R. (1996). Biological invasions as global environmental change. American Scientist, 84, 468-478.

Warren, A., Bell, M., \& Budd, L. (2010). Airports, localities and disease: Representations of global travel during the H1N1 pandemic . Health and Place, 16(4), 727-735.

Weber, R. P. (1990). Basic content analysis. Beverly Hills, CA: Sage.

Werthner, H., \& Klein, S. (1999). Information technology and tourism: A challenging relationship. Vienna: Springer.

Wilson, M. E. (2003). The traveller and emerging infections: Sentinel, courier, transmitter. Journal of Applied Microbiology, 94, $1-11$.

Wittenberg, R., \& Cock, M. J. W. (2001). Invasive alien species: A toolkit of best prevention and management practices. Wallingford, Oxon, UK; New York: CABI Publication.

World Health Organisation (WHO] (2016). Ebola situation reports. Retrieved 06/02/2018 from http://apps.who.int/ebola /ebola-situation-reports

WHO. (2014a). Ebola virus disease-United States of America. Retrieved 06/02/2018 from http://www.who.int/csr/don/01october-2014-ebola/en/

WHO. (2014c). Nigeria is now free of Ebola virus transmission. Retrieved 06/02/2018 from http://www.who.int/mediacentre/ news/ebola/20-october-2014/en/index1.html

WHO. (2014b). Ebola virus disease-United Kingdom. Retrieved 06/02/2018 from http://www.who.int/csr/don/30-december2014-ebola/en/

WHO. (2018). Ebola virus disease. Retrieved 06/02/2018 from http://www.who.int/mediacentre/factsheets/fs103/en/

Xiang, Z. (2018). From digitization to the age of acceleration: On information technology and tourism. Tourism Management Perspectives, 25, 147-150.

Zhu, W., Zhang, L., \& Li, N. (2014). Challenges, function changing of government and enterprises in Chinese smart tourism. Dublin: International Federation for IT and Travel \& Tourism (IFITT). 